\title{
SEROLOGICAL SURVEY OF CAPRINE TOXOPLASMOSIS IN ETHIOPIA: PREVALENCE AND RISK FACTORS
}

\author{
TESHALE S.*, DUMÈTRE A.**, DARDÉ M.L.**, MERGA B.** \& DORCHIES P.***
}

\section{Summary:}

The study was conducted to determine the prevalence and risk factors of toxoplasmosis in goats in Southern and central Ethiopia between October 2005 and May 2006. A total of 641 goats sera were tested using Modified Direct Agglutination Test (MAT), of which $480(74.8 \% \mathrm{Cl}: 71.3,78.2)$ were found to be positive. The highest prevalence was recorded in South Omo zone (82 \%) while the lowest was observed in East Shewa zone (62.2\%). The study revealed that goats raised in southern Ethiopia are at a greater risk of acquiring $T$. gondii infection $(O R=2.55$, Cl: $1.726,3.776 ; p=0.000$ ) than those which are raised in central Ethiopia. The prevalence of anti $T$. gondii antibody was significantly higher in older goats than in kids $\mid O R=2.33, \mathrm{Cl}$ : $1.490,3.655 ; p<0.0002)$ and in females than in males $(p<0.0007 ; O R=0.68, C l: 0.542,0.849)$. No significant difference was observed among goats kept under various husbandry practices. The high prevalence of toxoplasmosis in Ethiopian goats suggests a high risk of human infections. Further epidemiological investigation, isolation and genotyping of T. gondii are planed.

KEY WORDS : Toxoplasma gondii, goat, MAT, Ethiopia.
Résumé : ÉTUdE SÉROLOGIQUE DE LA TOXOPLASMOSE CAPRINE EN ÉTHIOPIE : PRÉVALENCES ET FACTEURS DE RISQUE

Cette étude a été réalisée pour déterminer la séroprévalence et les facteurs de risques de la toxoplasmose caprine dans le sud et le centre de l'Éthiopie. Entre octobre 2005 et mai 2006, sur 641 chèvres testées par une technique d'agglutination directe haute sensibilité, $480(74,8 \%$ IC: $71,3,78,2)$ ont été trouvées positives. La plus forte séroprévalence a été observée dans la partie sud de l'Omo (82 \%) et la plus faible dans l'Est de Shewa $(62,2 \%)$. Les chèvres élevées dans le sud de l'Éthiopie sont plus à risque d'acquérir une infection toxoplasmique que celles élevées en Éthiopie centrale. La prévalence des anticorps anti-T. gondii est significativement plus élevée chez les chèvres âgées que chez les chevreaux $\mid O R=2,33,1 C: 1,490,3,655 ; p<0,0002)$ et chez les femelles que chez les mâles $(p<0,0007 ; O R=0,68$, IC: $0,542,0,849)$. Aucune différence significative n'est observée en fonction des conditions d'élevage. La forte prévalence de la toxoplasmose chez les chèvres en Éthiopie suggère un risque élevé de toxoplasmose humaine. D'autres recherches épidémiologiques ainsi que des essais d'isolement et de génotypage des souches de toxoplasmes seront réalisés ultérieurement.

MOTS CLÉS : Toxoplasma gondii, chèvre, MAT, Éthiopie.

raised under various agro-ecological zones, however, only few studies have been carried out (Bekele \& Kassali, 1989; Tamiru et al., 2004; Tilaye \& Getachew, 2002) that were geographically limited to central Ethiopia. Results of the previous studies have shown that prevalence of anti T. gondii antibodies ranged from $11.9 \%$ to $35 \%$. In that country, the causes of most abortions, stillbirths and neonatal mortalities in flocks of goats remain unexplored and the relationship with seroprevalence of toxoplasmosis has not been investigated. The objectives of this study were, therefore, to determine seroprevalence and some risk factors of caprine toxoplasmosis in Ethiopia in specified study areas.

\section{MATERIALS AND METHODS}

** EA 3174, Neuroparasitologie et neuroépidemiologie tropicale, Faculté de Médecine, rue du Docteur Marcland, 87025 Limoges, France.

**:* Laboratoire de Parasitologie, UMR 1225, École Nationale Vétérinaire, 23, chemin des Capelles, BP 87 614, 31076 Toulouse cedex 03, France.

Correspondence: Ph Dorchies.

Tel.: +335611938 71 - Fax: +33561193944.

E-mail: p.dorchies@envt.fr
- Study areas

The study was conducted in southern Ethiopia (North Omo and South Omo) and central Ethiopia (East Shewa zone) from October 2005 to May 2006 (Table I and Fig. 1). 


\begin{tabular}{|c|c|c|c|c|c|}
\hline Region of sampling* & Altitude & Annual temperature & Rainfall & Climate & $\begin{array}{l}\text { Number of } \\
\text { goats tested }\end{array}$ \\
\hline \multicolumn{6}{|l|}{ East Shewa ${ }^{1}$} \\
\hline $7^{\circ} 9^{\prime} \mathrm{N}, 38^{\circ} 7^{\prime} \mathrm{E}$ & $1,650 \mathrm{~m}$ & $12.7-27^{\circ} \mathrm{C}$ & $760.9 \mathrm{~mm}$ & Semi-arid & 209 \\
\hline \multicolumn{6}{|l|}{ North $\mathrm{Omo}^{2}$} \\
\hline $6^{\circ} \mathrm{N}, 36^{\circ}-38^{\circ} \mathrm{E}$ & $>1,650 \mathrm{~m}$ & & $>1,000 \mathrm{~mm}$ & Warm and moist & 176 \\
\hline $\begin{array}{l}\text { South Omo } \\
4^{\circ}-5^{\circ} \mathrm{N}, 36^{\circ}-38^{\circ} \mathrm{E}\end{array}$ & $391-1,500 \mathrm{~m}$ & $11.2-32^{\circ} \mathrm{C}$ & $275.6 \mathrm{~mm}$ & Semi-arid & 256 \\
\hline
\end{tabular}

$*$ : numbers refer to the place on Figure 1.

Table I. - Location and climatic conditions of the study areas.

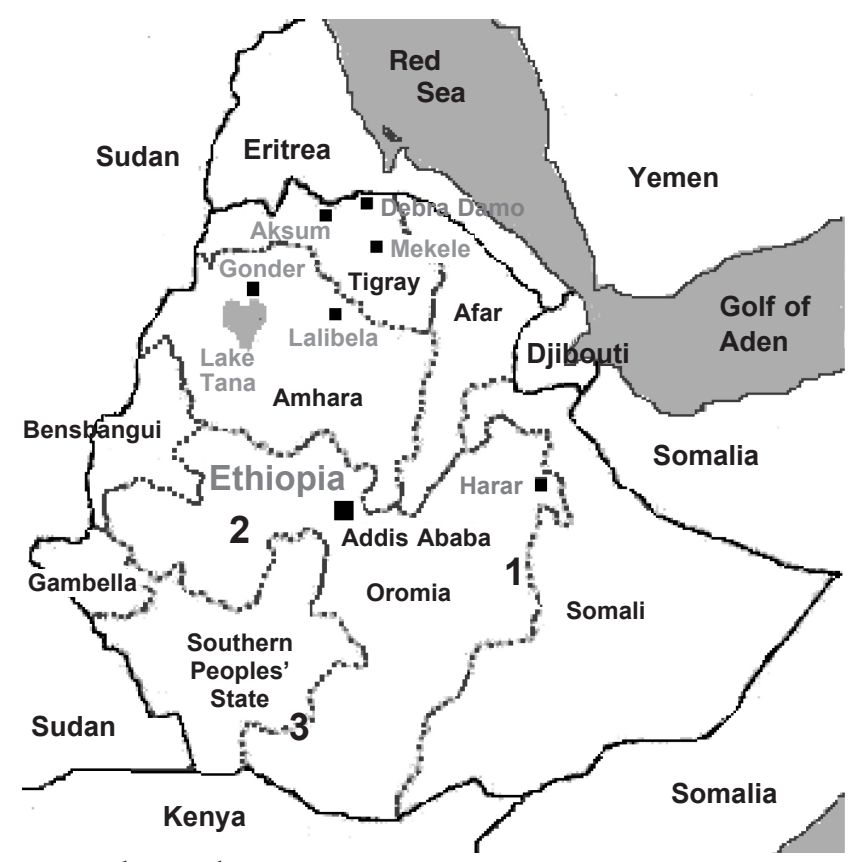

1,2 and 3: Study areas.

Fig. 1. - Map of Ethiopia showing study sites.

- Study design and sampling strategy

Cross-sectional study was conducted in different age and sex groups of goats. The goats included in this study were local breeds as Woyto-Guji and Boran-Arsi goats. Multistage and cluster sampling technique was employed to collect sera from study subjects.

- Serum Collection

Blood was collected by jugular vein puncture from 641 goats and the sera separated were stored at $-20^{\circ}$ until serological test was performed.

- Antigen preparation

The antigen for Modified Direct Agglutination Test (MAT) was produced in the peritoneal cavity of Swiss white albino mice as described by Desmonts \& Remington (1980). Formalin fixed whole tachyzoites of $T$. gondii harvested from peritoneal cavity of mice co-infected with RH strain of T. gondii and TG 180 mouse sarcoma cells was employed as antigen. The final concentration of antigen was adjusted to about 15,000 tachyzoites $/ \mu 1$ based on the recommendation of OIE (2004).

- Serological analysis

The caprine sera were analyzed by MAT using "U" bottom micro plates. The sera were tested at dilutions of $1 / 20,1 / 40$ and $1 / 400$ to avoid the prozone pheno-

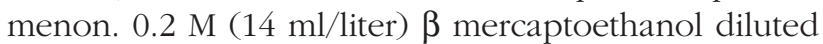
in PBS was incorporated into the test system to inhibit non-specific agglutination due to IgM antibodies (Desmonts \& Remington, 1980). Positive and negative controls were also tested alongside the test sera as references. Agglutination forming large carpet covering greater than $50 \%$ of the bottom of the wells was considered positive. Sedimentation forming a point or a ring at the bottom of the wells of the plates was taken as negative reaction. Sera showing visible carpet of agglutination at dilution of $1 / 20$ or higher were assumed positive to Toxoplasma infection (Dubey, 1983). Sera, which have shown doubtful reaction, were retested.

- Data Analysis

Seroprevalence of toxoplasmosis and confidence intervals were determined using standard epidemiological methods. Association between the outcome variable (prevalence of toxoplasmosis) and the explanatory variables (risk factors) was analyzed by chi-square $\left(\chi^{2}\right)$ tests. Backward Logistic regression (at significance level of 0.15 ) was used to analyze the significance of factors that were significant with univariate analysis.

\section{RESULTS AND DISCUSSION}

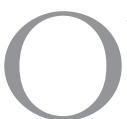
ut of 641 caprine sera tested $480(74.9 \%$, CI: $71.3 \%, 78.2 \%$ ) were found to be positive to anti $T$. gondii $\operatorname{IgG}$ antibodies. The seroprevalences were $82 \%, 79.5 \%$ and $62.2 \%$ in South Omo, North Omo and East Shewa zones, respectively. The world seroprevalence of toxoplasmosis in goats has been shown to have great variability, Tenter et al., 2000 indicated values from $0 \%$ to $77 \%$. In Africa, seroprevalence ranges from $6.4 \%$ (Djibouti) to $81.6 \%$ (Nigeria) for goats (Chantal et al., 1994; Arene, 1984). Geographical 


\begin{tabular}{|c|c|c|c|c|}
\hline Country & Test used & $\begin{array}{l}\text { Number of } \\
\text { animals tested }\end{array}$ & $\%$ positive & References \\
\hline \multicolumn{5}{|l|}{ Africa } \\
\hline Ethiopia & MAT & 60 & 26.7 & Tamiru et al., 2004 \\
\hline Ethiopia & MAT & 93 & 35 & Tilaye \& Getachew, 2002 \\
\hline Mali & DAT & 103 & 45 & Quilici et al., 1976 \\
\hline Ethiopia & IHAT & 753 & 11.6 & Bekele \& Kassali, 1989 \\
\hline Botswana & IHAT & 1,799 & 30 & Sharma et al., 2003 \\
\hline Sudan & IHAT & 134 & 63 & Zain Eldin et al., 1985 \\
\hline Tanzania & IHAT & 79 & 14.2 & Connor \& Halliwell, 1985 \\
\hline Nigeria & DT & 300 & 81.6 & Arene, 1984 \\
\hline Tunisia & DT & 85 & 60 & BenRachid \& Blaha, 1979 \\
\hline Uganda & ELISA & 784 & 31 & Bisson et al., 2000 \\
\hline Ghana & ELISA & 526 & 26.8 & Van den Puije et al., 2000 \\
\hline Zimbabwe & LAT & 211 & 7.5 & Pandey et al., 1992 \\
\hline Djibouti & IFAT & 1,081 & 6.4 & Chantal et al., 1994 \\
\hline Ivory coast & IFAT & & 68 & Deconinck et al., 1996 \\
\hline \multicolumn{5}{|l|}{ The Americas } \\
\hline USA & MAT & 99 & 65 & Patton et al., 1990 \\
\hline USA & IHAT & 99 & 55 & Patton et al., 1990 \\
\hline Venzuela & IHAT & 438 & 6.3 & Nieto \& Melendez, 1998 \\
\hline Brazil & ELISA & 174 & $3.7-71.8$ & Figueiredo et al., 2001 \\
\hline Brazil & IFAT & 213 & 40.4 & Silva et al., 2003 \\
\hline Brazil & LAT & 439 & 28.93 & Pita Gondim et al., 1999 \\
\hline \multicolumn{5}{|l|}{ Others } \\
\hline Iran & LAT/IHAT & 530 & 19.25 & Hashemi-Fesharki, 1996 \\
\hline Iran & ELISA & 200 & 15 & Ghazaei, 2005 \\
\hline Italy & IFAT & 2,445 & 12.3 & Masala et al., 2003 \\
\hline Czech & IFAT & 129 & 66 & Slosarkova et al., 1999 \\
\hline Malaysia & MAT & 400 & 35.2 & Dorny et al., 1993 \\
\hline Netherlands & MAT & & $5-90$ & Antonis et al., 1998 \\
\hline Sri Lanka & MAT & 139 & 22.3 & Dorny \& Van Aken, 1992 \\
\hline Afghanistan & IHAT & 171 & 31.6 & Kozojed et al., 1976 \\
\hline New Zealand & LAT & 298 & 37 & Opel et al., 1991 \\
\hline Indonesia & LAT & 160 & 47.5 & Matsuo et al., 1996 \\
\hline Over 40 countries & Various tests & & $0-77$ & Tenter et al., 2000 \\
\hline
\end{tabular}

Table II. - Seroprevalence of $T$. gondii infections in goats from previous reports.

variation in prevalence occurs not only among different continents or countries but also within a given country. The current prevalence is higher than the prevalence of caprine toxoplasmosis reported in Ethiopia and elsewhere (Table II). The greater prevalence of toxoplasmosis in the current study could emanate from difference in the serological tests employed, the sample size and geographical variability. In Ethiopia, previous studies were performed on fewer numbers of animals and were limited to the cooler areas of central Ethiopian. Our study was based on relatively larger number of animals inhabiting various regions with different agro ecologies. In addition, we employed Modified Agglutination Test, which was found to be superior in performance to most other serological tests (Klun et al., 2005). Previous workers reported seropositivity at dilutions $>1 / 32$ but we reported starting from $1 / 20$ dilutions. However, our result is comparable with the reports of Slosarkova et al. (1999); Arene (1984); Zain Eldin et al. (1985); Antonis et al. (1998); Patton et al. (1990); Figueiredo et al. (2001); Ben Rachid \& Blaha (1979) and Klun et al. (2005).
In support of the mentioned local variations, our study showed that goats from southern Ethiopia are at higher risk of $T$. gondii infection than those in the Rift valley region. Southern Ethiopia has warm and moist weather while the central region is characterized by its hot and dry climate. Moreover, the selected study sites from southern Ethiopia are located at the vicinity of Mago and Nech Sar national parks where large variety of wild fauna including felids are found. Domestic animals share the same environment with these wild animals whenever there is shortage of grazing land. Both situations have positive impact on the persistence and dissemination of oocysts of $T$. gondii. The influence of the environment and wild animals on the epidemiology of toxoplasmosis has been well documented (Frenkel, 1990; Tenter et al., 2000; Dubey, 2004).

The results of multivariate analysis using logistic regression model indicated that gender, study site and age have significant effect on the prevalence of toxoplasmosis. There was statistically significant difference $\left(\chi^{2}=\right.$ $56.1, \mathrm{p}<0.0002)$ in the prevalence of anti $T$. gondii antibodies among different age groups of goats. The 
prevalence was lower in the younger goats $(<1$ year) $(57.37 \%$, CI: $48.1 \%, 66.3 \%)$ than in the yearlings (> 1 year) ( $83.8 \%$, CI: $80 \%, 87.1 \%)$. Older goats were at higher odds $(\mathrm{OR}=2.33)$ of Toxoplasma infection than kids. This difference in prevalence among age group is partly due to cumulative effect of age. Older goats as they lived longer are more likely to encounter oocysts of $T$. gondii from the environment.

The significantly higher $\left(\chi^{2}=14.6 ;\right.$ OR $=0.68 ; \mathrm{P}=$ $0.0007)$ prevalence of $T$. gondii infection in young females $(80.5 \%$, CI: $75.8 \%, 84.6 \%)$ than in young males (74.5\%, CI: $65.5 \% 82 \%)$ was consistent with some previous reports (Okoh et al., 1981; Tamiru et al., 2004). But it was not found by other authors (Tilaye \& Getachew, 2002). The fact that female goats are kept for longer period of time for breeding and milk production purposes than males may have contributed for the relatively higher prevalence in does. Male animals are the ones that are frequently sold and only fewer bucks are found per flock. On agro-ecological basis, it was shown that goats raised in southern Ethiopian region are at greater risk of $T$. gondii infections $\left(\chi^{2}=26.5 ;\right.$ OR $\left.=2.55 ; \mathrm{p}=0.000\right)$ than goats raised in the Rift valley region. The seroprevalence was $81 \%$ (CI: 77, 84.6) in southern Ethiopia while it was $62.2 \%$ (CI: $55.3,68.8$ ) for Rift valley area. The absence of difference on the basis of management can be explained by the apparent absence of variation in husbandry practices that could have prevented access of cats to the grazing areas. The grazing areas in all the cases were open and can allow the pasture to be contaminated with cat feces. The high prevalence of toxoplasmosis reported in this study is a good marker of high risk for human infections since goats are important sources of meat in most parts of Ethiopia. Further epidemiological investigations and isolation and characterization of the genotypes of $T$. gondii are underway.

\section{ACKNOWLEDGEMENTS}

T The French Embassy is highly acknowledged for the financial support it provided for the accomplishment of this study. The authors are also highly thankful to the National Veterinary Institute and Akililu Lemma Institute of Pathobiology for their valuable support and provision of materials. Special gratitude goes to Drs. Berhe G/Egiabher, Gobena Ameni and Gelagay Ayelet.

\section{REFERENCES}

Antonis A.F., van Knapen F., Dercksen D.P. \& Jager P.M. Toxoplasmosis in goats in the Netherlands: a pilot study. Tijdschr Diergeneeskd, 1998, 123, 561-565.
ARENE F.O.I. The prevalence and public health significance of Toxoplasma gondii in indigenous meat animals in the Niger delta. Tropical Medicine and Parasitology, 1984, 35, 133-135.

Bekele T. \& Kassali O.B. Toxoplasmosis in sheep, goats and cattle in central Ethiopia. Veterinary Research Communications, 1989, 13, 371-375.

Ben RaChID M. \& Blaha R. La toxoplasmose humaine et animale en Tunisie. La Tunisie Médicale, 1979, 48, 10-110.

Bisson A., Maley S., Rubaire-Akitki C.M. \& Wastling J.M. Seroprevalence of antibodies to Toxoplasma gondii in domestic goats in Uganda. Acta Tropica, 2000, 76, 33-38.

Chantal J., Dorchies Ph. \& Legueno B. Study on some Zoonoses in Djibouti Republic. Revue de Médecine Vétérinaire, 1994, 145, 633-640.

ConNor R.J. \& Halliwell R.W. A serological survey of the prevalence of Toxoplasma gondii in goats and sheep in southern Tanzania. Annals of Tropical Medicine and Parasitology, 1985, 79, 111-112.

Deconinck P., Pangui L.J., AKakpo J., Garrouste A., Ouattara L., Roger F., Tibayrenc, R. \& Dorchies P. Sero-epidemiology of toxoplasmosis in sheep and goats from Africa. Revue de Médecine Vétérinaire, 1996, 147, 377-378.

Desmonts G. \& Remington J.S. Direct agglutination test for diagnosis of Toxoplasma infection: method for increasing sensitivity and specificity. Journal of Clinical Microbiology, 1980, 11, 562-568.

Dorny P., Casman C., SAni R. \& Vercruysse J. Toxoplasmosis in goats: a seroepidemiological study in Peninsular Malaysia. Annals of Tropical Medicine and Parasitology, 1993, 87, 407-410.

DORNY P. \& VAN AKEN D. Prevalence of Toxoplasma gondii antibodies in goats in Srilanka. Annals of Tropical Medicine and Parasitology, 1992, 86, 83-85.

Dubey J.P. Persistence of encysted Toxoplasma gondii in caprine livers and public health significance in goats. Journal of the American Veterinary Medical Association, 1980, 177, 1203-1207.

DuBEY J.P. Distribution of cysts and tachyzoites in calves and pregnant cows inoculated with Toxoplasma gondii oocysts. Veterinary Parasitology, 1983, 13, 199-211.

DubEY J.P. Toxoplasmosis a water borne zoonoses. Veterinary Parasitology, 2004, 126, 57-72.

Figueiredo J.F., Silva D.A.O., Dagmar D., Cabral D.D. \& Mineo J.R. Seroprevalence of Toxoplasma gondii infection in Goats by the Indirect Haemagglutination, Immunofluorescence and Immunoenzymatic Tests in the Region of Uberlândia, Brazil. Memórias do Instituto Oswaldo Cruz, 2001, 96, 687-692.

FrENKEL J.K. Toxoplasmosis in human beings. Journal of the American Veterinary Medical Association, 1990, 196, 240-246.

GHAZAEI C. Serological survey of antibodies to Toxoplasma. The Internet Journal of Veterinary Medicine, 2005, 2, n 1.

HASHEMI-FESHARKI R. Prevalence of Toxoplasma gondii in cattle, sheep and goats in Iran. Veterinary Parasitology, 1996, 61, 1-3.

Kuun I., Djurkovic-Djakovic O., Katic-Radivojevic S. \& Nikolic A. Cross-sectional survey on Toxoplasma gondii in Serbia. Veterinary Parasitology, 2005, 135, 121-131. 
Kozojed V., BlazeK K. \& Amin A. Incidence of toxoplasmosis in domestic animals in Afghanistan. Folia Parasitologica, 1976, 23, 272-275.

Masala G., Porcu R., Madau L., Tanda A., Ibba B., Satta G. \& Tola S. Survey of ovine and caprine toxoplasmosis by IFAT and PCR assays in Sardinia, Italy. Veterinary Parasitology, 2003, 117, 15-21.

Matsuo K. \& Husin D. A survey of Toxoplasma gondii antibodies in goats and cattle in Lampung province, Indonesia. Southeast Asian Journal of Tropical Medicine and Public Health, 1996, 27, 554-555.

Nieto S.O. \& Melendez R.D. Seroprevalence of Toxoplasma gondii in goats from arid zones of Venzuela. Journal of Parasitology, 1998, 84, 190-191.

Окон A.E.J., Agbonlahor D.E. \& Momн M. Toxoplasmosis in sheep and goats. Tropical Animal Health and Production, 1981, 13, 137.

Opel U., Charleston W.A., Pomroy W.E. \& Rommel M. A survey of the prevalence of Toxoplasma infection in goats in New Zealand and a comparison of the latex agglutination and indirect fluorescence tests. Veterinary Parasitology, 1991, 40, 181-186.

OfFice InTERnational des ÉpIzOOTIEs (OIE). Toxoplasmosis in: Manual of standards for diagnostic tests and vaccines, 2004, 2, 10-12.

PANDEY V.S. \& VAN KNAPEN F. The seroprevalence of toxoplasmosis in sheep, goats and pigs in Zimbabwe. Annals of Tropical Medicine and Parasitology, 1992, 86, 313-315.

Patton S., Johnson S.S. \& PUCKetT K. Prevalence of Toxoplasma gondii antibodies in nine populations of dairy goats: compared titers using modified direct agglutination and indirect hemagglutination. Journal of Parasitology. 1990, 76, 74-77

Pita Gondim L.F., Barbosa H.V., Ribeirofilho C.H. \& Saeki H. Serological survey of Toxoplasma gondii in goats, sheep, cattle and water buffaloes in Bahia state, Brazil. Veterinary Parasitology, 1999, 82, 273-276.

Quilici M., Ranque P., Tounkara A. \& Rougemont A. La toxoplasmose en République du Mali. Approche épidémiologique. Acta Tropica, 1976, 33, 229-239.

Sharma S.P., Baipoledi E.K., Nyange J.F.C. \& Tlagae L. Isolation of $T$. gondii from goats with a history of reproductive disorders and the prevalence of Toxoplasma and chlamydial antibodies. Onderstepoort Journal of Veterinary Research, 2003, 70, 65-68.

Silva A.V., Cunha E.L.P., Meireles L.R., GotTschalk S., Mota R.A. \& Langoni H. Sheep and goat toxoplasmosis: seroepidemiological study in two regions in the State of Pernambuco, Brazil. Revista Ciência Rural, 2003, 33, 115-119.

Slosarkova S., Literak I., Skrivanek M., Svobodova V., Suchy P. \& Herzig I. Toxoplasmosis and Iodine deficiency in Angora goats. Veterinary Parasitology, 1999, 81, 89-97.

Tamiru N., Getachew T., Patton S., Prevot F. \& Dorchies P. Serological survey of toxoplasmosis in sheep and goats in Nazareth, Ethiopia. Revue de Médecine Vétérinaire, 2004, 155, 486-487.

Tenter A.M., Heckeroth A.R. \& Weiss L.M. Toxoplasma gondii: from animals to humans. International Journal for Parasitology, 2000, 30, 1217-1258.
Tilaye D. \& Getachew T. Study on toxoplasmosis in sheep and goats in Debre Berhan and the surrounding areas in central Ethiopia. Bulletin of Animal Health and Production in Africa, 2002, 50, 138-147.

Van Den Puije W.N.A., Bosompem K.M., Cancoo E.A., WastLING J.M. \& AKANMORI B.D. The prevalence of anti Toxoplasma gondii antibodies in Ghanian sheep and goats. Acta Tropica, 2000, 76, 21-26.

Zain Eldin E.A., ElKhawad S.E. \& KHeIR S.M. A serological survey for Toxoplasma antibodies in cattle, shep, goats and camels (Camelus dromedarius) in the Sudan. Revue d'Élevage et de Médecine Vétérinaire des Pays Tropicaux, 1985 , 38, 247-249.

Reçu le 11 octobre 2006 Accepté le 5 février 2007 